Etnográfica

Revista do Centro em Rede de Investigação em

Antropologia

vol. 13 (2) | 2009

Vol. $13(2)$

\title{
A narrativa da degradação ambiental no Sul da Guiné-Bissau: uma desconstrução etnográfica
}

The narrative of environmental degradation in Southern Guinea-Bissau: an ethnographic deconstruction

\section{Marina Padrão Temudo}

\section{(2) OpenEdition}

\section{Journals}

Edição electrónica

URL: https://journals.openedition.org/etnografica/1341

DOI: 10.4000/etnografica.1341

ISSN: 2182-2891

\section{Editora}

Centro em Rede de Investigação em Antropologia

\section{Edição impressa}

Data de publição: 1 novembro 2009

Paginação: 237-264

ISSN: 0873-6561

\section{Refêrencia eletrónica}

Marina Padrão Temudo, «A narrativa da degradação ambiental no Sul da Guiné-Bissau: uma desconstrução etnográfica», Etnográfica [Online], vol. 13 (2) | 2009, posto online no dia 22 abril 2013, consultado o 10 fevereiro 2022. URL: http://journals.openedition.org/etnografica/1341 ; DOI: https:// doi.org/10.4000/etnografica.1341

\section{(c) (i) (8)}

Etnográfica is licensed under a Creative Commons Attribution-NonCommercial 4.0 International License. 


\title{
A narrativa da degradação ambiental no Sul da Guiné-Bissau: uma desconstrução etnográfica ${ }^{1}$
}

\author{
Marina Padrão Temudo
}

\begin{abstract}
Neste artigo, através de um estudo de caso, é analisada a complexidade da relação entre crescimento populacional, agricultura e gestão sustentável dos recursos naturais e o reducionismo das designadas "narrativas da degradação ambiental”. Do ponto de vista epistemológico e metodológico pretende-se também demonstrar as vantagens da investigação empírica de cariz etnográfico e do seu complemento com a técnica de detecção remota e os sistemas de informação geográfica no estudo das alterações da paisagem, do impacte das estratégias produtivas dos agricultores e das múltiplas variáveis que condicionam as mudanças nos sistemas tradicionais de gestão dos recursos naturais.
\end{abstract}

PALAVRAS-CHAVE: parques naturais, população, contranarrativa, etnoagronomia, detecção remota, Guiné-Bissau.

\section{O LEGADO DE MALTHUS}

A prática do desenvolvimento tem sido enformada por um discurso hegemónico, através do qual África nos é retratada como um continente com elevado crescimento demográfico, fraco ou inexistente progresso industrial e tecnológico e atravessando uma incomensurável crise social, agrícola e ambiental.

1 Este artigo foi concebido no âmbito do projecto "Land cover changes and successional pathways in the forests of Cantanhez, Guinea-Bissau" (PPCDT/BIA-BDE/57965/2004), financiado pela Fundação para a Ciência e a Tecnologia (FCT). Agradeço a Viriato Cassamá pela cedência dos mapas das alterações do coberto vegetal (fig. 4) e a Luís Catarino, investigador principal do projecto, pela frequente troca de ideias. Uma versão anterior deste texto foi apresentada como aula de agregação ao Departamento de Economia Agrária e Sociologia Rural do Instituto Superior de Agronomia e beneficiou das críticas de Adolfo Yañez Casal, Jorge Braga de Macedo e José Dinis Reis. José Miguel Cardoso Pereira, Albert Roca, Maria José Vasconcelos e os dois referees anónimos da Etnográfica também contribuíram com comentários importantes. Os meus maiores agradecimentos vão, no entanto, para os agricultores de Cubucaré, que ao longo de quinze anos colaboraram na minha pesquisa e me privilegiaram com a sua amizade. 
O estabelecimento de uma relação directa entre o crescimento da população, a degradação ambiental e os conflitos sociais - tão importante em termos científicos e políticos - tem raízes que remontam ao economista britânico Thomas Robert Malthus (1766-1834), um dos fundadores da demografia moderna. A sua abordagem consistia em considerar o território e a disponibilidade reduzida de recursos como os limites para o crescimento da população (Gausset e Whyte 2005). Malthus alegava que em todas as épocas existe uma taxa de crescimento demográfico possível, à qual o crescimento da população tenderia a ajustar-se, e que as fomes - motivadas por um défice absoluto de alimentos - eram o principal factor na regulação do crescimento populacional (Malthus 1826 [1798]).

Ester Boserup (1965; 1981), mais de um século depois, destaca-se entre os maiores críticos do pensamento malthusiano. Para ela, o crescimento populacional constitui um estímulo para o desenvolvimento de tecnologias geradoras de uma maior produtividade da terra e do trabalho, na medida em que a intensificação da agricultura que dele decorre (que obriga à progressiva conversão da agricultura itinerante em permanente) conduz a uma diminuição da fertilidade do solo e a um crescente investimento em trabalho. Como referem Gausset e Whyte (2005: 12), para Boserup o crescimento da produção não tem um limite fixo, dado que é sempre possível encontrar novas soluções tecnológicas para o problema da escassez.

A questão ambiental veio a adquirir um lugar proeminente na problemática população versus recursos, através da corrente de pensamento defendida pelos designados "neomalthusianos" (Leach e Fairhead 2000). Para estes, o desequilíbrio entre o crescimento da população e os recursos disponíveis conduz à estagnação da agricultura e à degradação ambiental, que por sua vez irá reforçar esse desequilíbrio numa espiral descendente (Cleaver e Shreiber 1994). Considerando que os recursos estão a diminuir, muitos neomalthusianos argumentam que terão de ser criadas medidas para reduzir o crescimento populacional (e.g. Ehrlich e Ehrlich 1993). Em "The tragedy of the commons", Hardin (1968) alega que, no caso dos recursos comunais, as consequências são ainda mais negativas, pois é suposto que cada indivíduo seja motivado para tentar extrair o máximo de benefícios. Este trabalho tornou-se um ideário para os neomalthusianos e tem vindo a dar corpo às políticas e abordagens conservacionistas. Para aqueles, o Estado deve intervir e/ou privatizar os recursos colectivos, de forma a evitar que os beneficiários pilhem irremediavelmente os recursos comuns. De acordo com este cenário, os conflitos sociais são percebidos como uma consequência inevitável e permanente da escassez (Gausset e Whyte 2005: 12). Esta é a perspectiva adoptada pelos proponentes de uma das teorias explicativas das chamadas "novas guerras" do pós-Guerra Fria, designada por Richards (2005: 6) "Malthus com armas".

No extremo oposto da posição defendida por Garrett Hardin surgiu uma corrente suportada pelas conclusões da Convenção do Rio sobre biodiversidade 
e o saber local das populações "indígenas" (UNCED 1992). Advoga que, em muitos casos, os sistemas de posse comunal da terra apresentam um grande potencial para a gestão sustentável dos recursos naturais. Esta nova abordagem é agora defendida também por muitos dos técnicos e investigadores associados ao Banco Mundial (Burnham 2000: 39, 40).

O modelo de Boserup tem vindo a ser desenvolvido por investigadores que demonstraram que uma maior pressão demográfica não conduz necessariamente à degradação ambiental e pode, pelo contrário, dar origem ao desenvolvimento de técnicas para uma melhor conservação do solo e da água e a uma mais eficiente gestão dos recursos florestais (e.g. Tiffen, Mortimore e Gichuki 1994). A destruição das florestas tropicais, devido ao seu abate para fins agrícolas, energéticos (sobretudo produção de carvão para usos domésticos) e para a exploração das madeiras valiosas, tem servido como bandeira das intervenções ambientalistas que visam a preservação da biodiversidade vegetal e animal. Em África, a agricultura itinerante (que envolve corte e queima da vegetação) tem sido considerada, desde os tempos coloniais, a principal causa de desflorestação (Ickowitz 2006). Na percepção ecologista mais ortodoxa, as actuais manchas florestais representam relíquias de uma anterior cobertura mais vasta de floresta primária, que a intervenção humana destruiu. Face às designadas "narrativas da degradação ambiental", autores como James Fairhead e Melissa Leach (e.g. 1996; 1998) têm vindo a desconstruir, a partir da antropologia social, o estereótipo de que os pequenos agricultores africanos conduziram ao longo dos tempos uma intensa desflorestação do continente. Através da análise etnográfica e da pesquisa histórica, demonstraram, pelo contrário, que uma avaliação objectiva da evolução do coberto vegetal evidencia, em muitos casos, que os agricultores contribuíram para um enriquecimento da paisagem e das florestas.

O papel do mercado é muitas vezes omitido na análise das relações população-ambiente ou considerado como uma das causas de agravamento da pressão sobre os recursos (e.g. Kotto-Same et al. 1997: 246). Porém, como o demonstraram Tiffen, Mortimore e Gichuki (1994), com um estudo de caso do distrito de Machakos no Quénia, o crescimento populacional, quando combinado com novas oportunidades de mercado, pode estimular a inovação e o investimento na criação de sistemas agrícolas sustentáveis, ainda que este processo possa ser favorecido ou atenuado/impedido por políticas governamentais.

Não subestimando a complexidade da relação entre população e recursos, a degradação ambiental nos trópicos pode ser, em parte, consequência do crescimento populacional. Os pequenos agricultores dispõem frequentemente de fracas alternativas tecnológicas, têm um acesso limitado a meios de produção, a crédito e a oportunidades de emprego fora da agricultura, o que agrava a pressão sobre os recursos em zonas de forte concentração da população. A "armadilha da pobreza" em que foram apanhados pode conduzi-los à sobreexploração dos recursos naturais (Huijsman e Savenije 1991). 
Se as experiências conservacionistas mais radicais, que implicaram a expulsão das populações das zonas a preservar, resultaram em situações de pobreza, conflito e erosão cultural (e.g. Cernea e Schmidt-Soltau 2006; Schmidt-Soltau 2003; Brockington 2002), as intervenções que adoptaram uma abordagem de gestão "comunitária" ou "colaborativa" fracassaram em grande parte dos casos (Leach e Fairhead 2001). O problema parece residir na aplicação de modelos-padrão, de um ou outro tipo, que não têm em conta cada contexto social, cultural, político e ecológico. Como sublinha Burnham (2000: 51, 52), por um lado, a questão ambiental tem servido para alimentar a "máquina do desenvolvimento", da qual depende a sobrevivência de numerosas instituições e o sustento de muitos funcionários; por outro, a complexidade na elaboração dos projectos parece ser inimiga da sua aprovação para financiamento e futura avaliação de resultados. A solução para a gestão sustentável das florestas tropicais assentaria no entanto, como defendem Leach e Fairhead (2001), na adopção de abordagens de intervenção processuais e adaptativas em vez de pré-planeadas.

O estudo de caso discutido neste artigo é fruto de uma investigação de cariz etnoagronómico, cujo trabalho de campo decorreu de 1993 a 2008 (35 meses em períodos de longa duração) e em que os principais instrumentos de recolha de informações foram a observação directa, a observação participante, as conversas informais e as entrevistas semiestruturadas. A possibilidade de comparação com os mapas elaborados por Cassamá (2006) - que retratam as alterações do coberto do solo, durante um período de 50 anos, com base em fotografia aérea e em imagens de satélite - permitiu suportar de forma inequívoca as conclusões da pesquisa etnográfica.

\section{HISTÓRIA DO POVOAMENTO E GESTÃO TRADICIONAL DOS RECURSOS NATURAIS EM CUBUCARÉ}

Cubucaré é uma península que possui uma superfície de cerca de $1142 \mathrm{~km}^{2}$, sendo delimitada a norte e a oeste pelos rios Cumbidjã e Balana, a este pelo rio Cacine e pela fronteira com a Guiné Conacri e ao sul pela ilha de Melo e pelo oceano Atlântico (figura 1).

Apesar de ser uma pequena região, apresenta uma multiplicidade etnolinguística muito acentuada. Nos primeiros relatos dos navegadores portugueses, os nalus são mencionados como os habitantes da região da Guiné-Bissau que hoje constitui a província de Tombali, da



Figura 1

Localização de Cubucaré. 
qual Cubucaré faz parte (Álvares de Almada 1964 [1594]: 11 1-1 17). Cerca de 1889, a região de Cubucaré começou a ser invadida pela etnia fula, o que obrigou os nalus que não foram feitos cativos a refugiarem-se, a pouco e pouco, nas ilhas de Como e Melo (Carvalho 1949: 313 ). Pouco antes do fim das chamadas "campanhas de pacificação", ${ }^{2}$ os nalus - preocupados com a crescente ameaça que representava a etnia fula, a quem mais tarde os portugueses, agradecidos pelo apoio militar prestado, irão mesmo entregar parte do território nalu de Cubucaré, correspondente ao actual regulado de Guiledge (Carvalho 1949; Frazão Moreira 1999: 46) - realizam cerimónias em que pedem aos espíritos (iras) "donos do chão" a vinda de "hóspedes" de outras etnias. O aumento da densidade populacional é desejado pelos "donos do chão" como estratégia de domesticação da natureza - nas palavras de um agricultor, "nesse tempo as onças eram mais do que as pessoas” -, mas sobretudo, hipótese já levantada por Frazão-Moreira (1999: 165), como estratégia política tendente a assegurar a hegemonia sobre o território face à pressão da etnia fula.

Nas primeiras décadas de 1900, ocorreram vagas sucessivas de imigração de outras etnias, das quais a primeira terá sido a sosso, oriunda da então Guiné Francesa e movida inicialmente por fins comerciais (Carvalho 1949: 317), a qual irá contribuir de forma decisiva para a islamização voluntária dos nalus e para o desenvolvimento da fruticultura. A etnia balanta - vinda do Norte à procura de terrenos de cultivo de arroz - começou a instalar-se em Cubucaré no início dos anos 20 do século passado, tornando-se maioritária a partir de 1949. Seguiram-se depois grupos de manjacos, pepéis e bijagós, atraídos sobretudo pelos grandes palmares (Carvalho 1949: 31 1, 312). Carreira (1962: 230), referindo-se a toda a região de Tombali, fala da importância dos balantas no "povoamento em massa de uma região até aí com população rarefeita (e em alguns pontos até desabitada)".

A distribuição espacial das quatro principais etnias encontra-se representada no mapa elaborado por A. Teixeira da Mota, onde também constam as principais povoações e os limites dos regulados (figura 2). No entanto, a etnia fula aparece sobrerrepresentada, dado que a área que lhe foi atribuída ultrapassa largamente o regulado de Guiledge, incluindo uma grande área do regulado de Cadique, onde a sua presença até hoje se limita a uma parte dos habitantes das povoações de Iemberém e de Madina de Iemberém. Repare-se que, de acordo com os dados do recenseamento populacional de 1991, os balantas representam $62 \%$ da população, os nalus 10\% e os fulas 8\% (Silva, Cardoso e Silva 2001: 9).

Em 1949, Carvalho (1949: 308) afirma que o sector de Cubucaré - antigo Posto de Bedanda - possuía já cerca de 10 mil habitantes, distribuídos por 63 povoações, situadas em três regulados: Guiledge, Cantanhez (actual regu-

2 Campanhas militares que se destinaram a assegurar a ocupação militar e administrativa portuguesa do território da Guiné e que terminaram em 1915 (Pélissier 1989). 


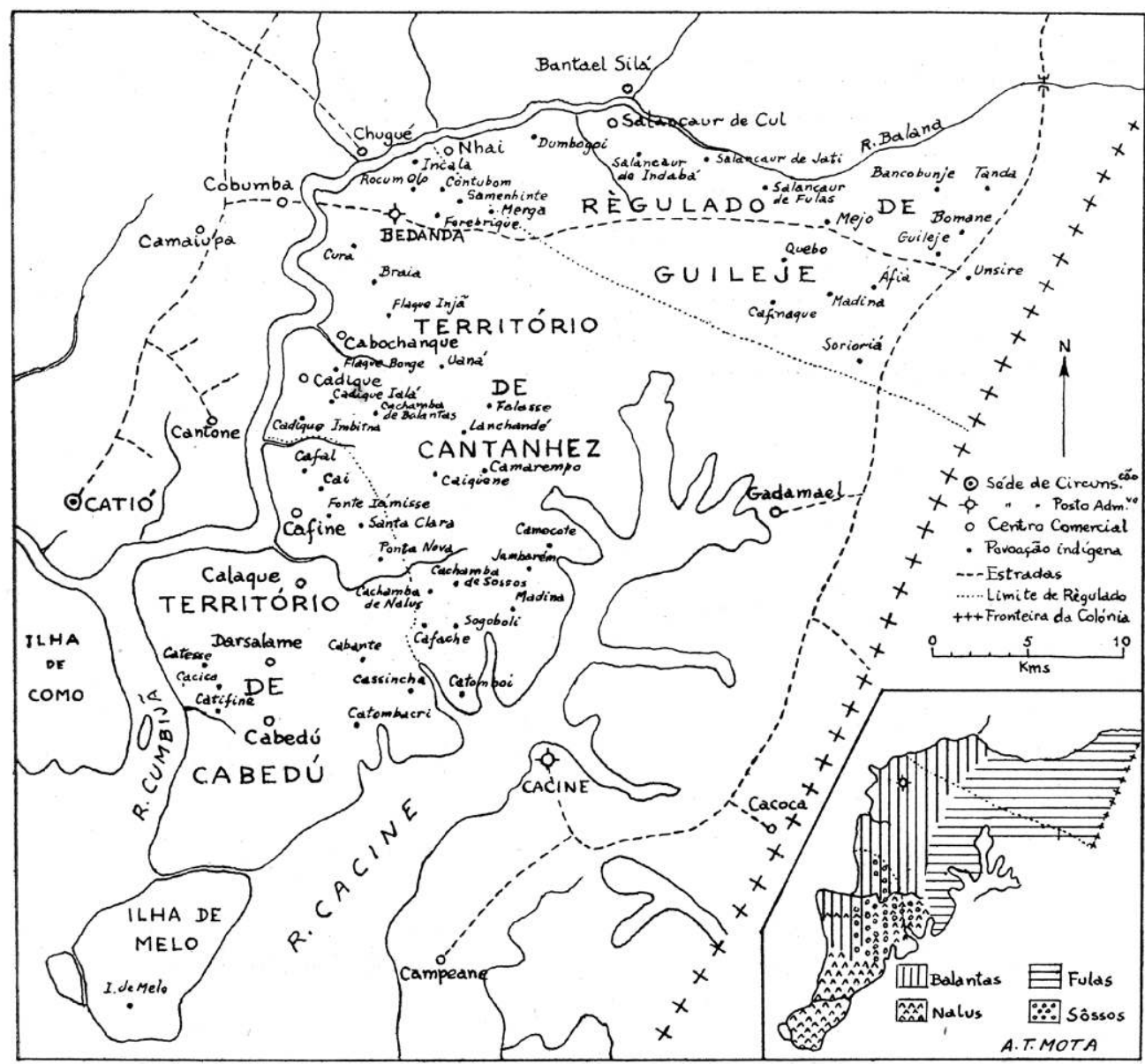

Figura 2 - Localização dos regulados, das povoações mais importantes e das principais etnias em Cubucaré. (Fonte: Carvalho 1949: 309)

lado de Cadique) e Cabedú. O primeiro recenseamento geral da população realizado após a independência indica uma população de aproximadamente 15 mil habitantes, com uma densidade populacional de cerca de 15 habitantes $/ \mathrm{km}^{2}$, distribuídos por 101 povoações (INEC 1979: 6). À data do censo de 1991, o sector possuía já uma população de cerca de 19 mil habitantes (INEC 1992), que aumenta para mais de 25 mil em 2007 (INEP/INEC 2007). A análise da figura 3, elaborada por Anginot (1988) com base no censo de 1979, evidencia uma maior concentração da população na faixa costeira ao longo dos rios Cumbidjã e Balana, onde se localiza a maioria da população balanta e os campos mais produtivos de arroz alagado. Pelo contrário, as margens do rio Cacine, onde os solos são de baixa fertilidade para o cultivo do arroz alagado, encontram-se fracamente povoadas. 
No estudo do povoamento da região é também de referir que, no período colonial, com excepção das grandes povoações onde existiam "centros de comércio" ou quartéis, a grande maioria das restantes estava instalada longe das vias rodoviárias, como estratégia de resistência ao pagamento dos impostos e ao trabalho forçado. Após a independência, muitas das povoações não balantas (as balantas estão geralmente localizadas próximo dos campos de arroz nas margens dos rios) destruídas durante a guerra deslocaram-se para a berma das estradas.

Como referido, os primeiros habitantes da península de Cubucaré, bem como de toda a província de Tombali, foram os nalus, razão pela qual esta região é vulgarmente conhecida por "Chão Nalu". Todos os povos da região partilham um conjunto de crenças, segundo as quais o território de Cubucaré é povoado por espíritos (iras) cujo mundo se encontra organizado à semelhança do humano. Em termos de estrutura de poder, o mundo dos iras está dividido como um

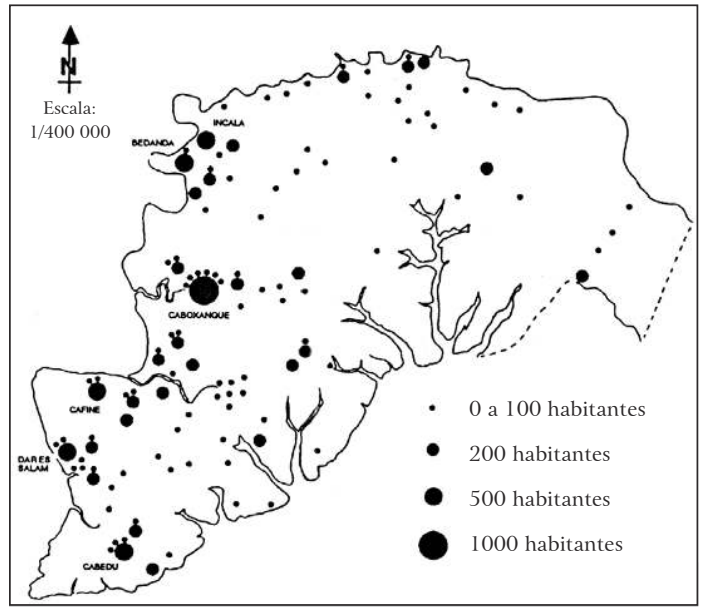

Figura 3 - Distribuição da população no sector de Cubucaré. (Adaptado de Anginot 1988: 38) país em diversas regiões, chefiadas por um "dono do chão", que actua em colaboração com outros iras "donos dos matos", "donos dos rios", "donos dos animais selvagens", e que possui as suas "sentinelas" situadas em pontos estratégicos. As fronteiras entre estas subdivisões estão claramente definidas por rios, árvores, acidentes naturais ou pedras. Cubucaré encontra-se assim dividido em diferentes províncias de espíritos (chãos), e o acesso à terra e aos restantes recursos naturais é controlado em cada um deles pelo chefe do grupo de descendência (djagra) que primeiro o povoou.

De acordo com a tradição, qualquer grupo doméstico (morança) que se instale na região tem direito de acesso a uma parcela de terreno suficientemente grande para assegurar o sustento dos seus membros. A partir do momento em que o terreno é atribuído, o seu detentor possui os direitos de usar e de fruir. O direito de dispor aplica-se exclusivamente à transmissão aos seus descendentes. Quando, pelo contrário, a transmissão vai ocorrer para fora da morança à qual o terreno foi concedido, o seu chefe deverá apresentar o futuro beneficiário aos "donos do chão", que de novo procederão aos rituais destinados a averiguar a aceitação do requerente pelo ira "dono do chão". Só as benfeitorias permanentes permitem a transmissão por venda, dado que a terra não 
é considerada uma mercadoria e o preço de venda é calculado em função dos investimentos permanentes (como diques e pomares) realizados.

A cosmologia nalu estabelece um conjunto de normas que, a um nível inconsciente, gera uma relação com a natureza que preserva a manutenção do equilíbrio ecológico (Temudo 1998, vol. I: 434, 435). Em cada "chão", o espaço encontra-se dividido em três grandes classes:

- o pertencente a cada povoação e que inclui terrenos de habitação e terrenos de cultivo;

- os "matos malgosse", ${ }^{3}$ que são pequenos nichos florestais (situados nas florestas densas sub-húmidas) onde se encontram os locais de culto e que pelas descrições são espaços relativamente circulares com um área inferior a um hectare. Nenhum recurso pode ser daí retirado - constituindo aquilo que se pode designar uma reserva integral - e o seu acesso está interdito às pessoas que não pertencem à linhagem "dona do chão", a não ser que acompanhadas por estas, quando vão fazer algum pedido ao ira que aí habita;

- áreas-tampão florestais que rodeiam os "matos magosse" e cujos recursos são de acesso limitado, i. e., a caça, a colheita de mel, de lenha, de frutos e de raízes silvestres são permitidas aos habitantes da região, mas o corte de grandes árvores para a construção de canoas, de pilões e de traves para casas está sujeito a um pedido de autorização. Diz-se que estas árvores estão protegidas ritualmente (mangidas) e que poderá acontecer algo de terrível a quem as tentar cortar sem autorização. $\mathrm{O}$ acesso a estas áreas está rodeado por uma aura mágico-religiosa que limita a entrada e o usufruto dos recursos. Estas zonas são também consideradas reservas de fundiário, que poderá vir a ser atribuído em parte no futuro.

A gestão dos recursos naturais das áreas-tampão está sob a alçada do "dono do chão" de cada território, que coloca representantes da sua linhagem na tabanca mais próxima de cada um dos "matos". A autorização para o corte de árvores de grande porte é dada por este, que indica de forma precisa qual a planta que pode ser cortada, em função do seu destino.

Nesta secção relatámos de forma atemporal o sistema de gestão dos recursos naturais dominante nos regulados de Cabedú e de Cadique. Omitiu-se porém que ele existe num contexto de pluralismo legal e que a hegemonia nalu sobre a gestão dos recursos naturais prevalece no quadro de uma relação de forças permanentemente negociada. No regulado de Guiledge, onde a etnia fula é considerada "dona do chão" desde o início da ocupação colonial 
efectiva, há uma relação material com os recursos naturais e não existem florestas sagradas.

\section{INOVAÇÃO AGRÍCOLA E RECURSOS FLORESTAIS}

A transformação de toda a região de Tombali no celeiro de arroz da Guiné-Bissau está associada à migração para esta região da etnia balanta, a qual introduziu o sistema de cultivo em fluvissolos após o corte da vegetação de mangal e a construção de um sofisticado sistema de diques e comportas (bolanha salgada). Até essa altura, o arroz era cultivado em sequeiro (sistema itinerante de corte e queima, designado pampam em crioulo) e em regime de alagamento nas zonas baixas interiores (bolanha doce). Os sistemas de produção passam, a partir dessa época, a estar intimamente associados à matriz étnica, podendo afirmar-se que a etnia balanta se encontra especializada na produção de arroz em bolanha salgada, as etnias fula e tanda na produção em sequeiro de arroz consociado com inúmeras outras espécies e as restantes etnias praticam os dois sistemas em diferentes graus (Anginot 1989).

A migração dos balantas para Tombali - em parte apoiada por concessionários de terra (ponteiros) - teve como consequência imediata um aumento extraordinário da produção de arroz da então colónia, que obrigou mesmo à criação da circunscrição civil de Catió (Carreira 1962: 221 , 224). A expansão da produção de arroz ${ }^{4}$ em Cubucaré decorreu até ao início da guerra anticolonial (1963). Muito embora a quase totalidade dos excedentes comercializados fosse proveniente de bolanha salgada, a grande maioria dos produtores de sequeiro era auto-suficiente e alguns produziam mesmo excedentes. Em Cubucaré, agricultores djacanca, tanda e sosso dedicavam-se à exportação de arroz para o país vizinho - fugindo ao controlo dos portugueses -, importando panos, tigelas e outros produtos que localmente trocavam por aquele cereal. A grande coesão da mão-de-obra familiar e de entreajuda e o número limitado de actividades geradoras de rendimentos monetários permitia a desflorestação de grandes áreas e a manutenção de períodos de pousio superiores a sete anos. $\mathrm{O}$ arroz constituía a principal cultura de rendimento, dado que a produção de amendoim era muito reduzida, sendo praticada nas zonas de savana por manjacos e mancanhas que migravam sazonalmente. A colheita de coconote, proveniente dos palmares espontâneos, era também uma grande fonte de rendimento para a população local.

A fruticultura foi progressivamente adquirindo importância durante o período colonial, mas a área por ela ocupada era relativamente reduzida, se

4 A título de exemplo, em Cadique, uma das principais povoações produtoras de arroz no tempo colonial, foi implantada a primeira loja em 1942 e em 1948 existia já um "centro de comércio" com oito lojas. 
omitirmos os pomares de coleira. Esta espécie foi introduzida pelos sossos e era plantada nas zonas baixas e húmidas em sistema agroflorestal, em pomares que para "não entendidos" pouco se distinguem das florestas originais. A importância económica desta produção em Cubucaré no tempo colonial mencionada por Carreira (1962: 224) - é demonstrada pelo facto de ser pago um imposto sobre os pomares, que eram recenseados. Mangueiras - primeira fruteira introduzida na região pelos nalus -, bananeiras e citrinos eram plantados essencialmente para autoconsumo ao redor das habitações.

No início da década de 1960 foram instalados em Cubucaré alguns pomares de cajueiros com recurso a trabalho forçado - a título de campos de demonstração -, como o ainda existente na tabanca de Cadique. Os produtores rurais não atribuíram então qualquer importância à cultura, muito embora o usufruto lhes coubesse, garantindo o Estado a compra dos frutos. Com efeito, o cultivo do cajueiro foi fomentado na Guiné pelo Comandante Sarmento Rodrigues, enquanto governador da então colónia, através de plantações conduzidas pelas autoridades administrativas. Em 1959, dada a sua grande rusticidade e adaptação às condições agroecológicas, é integrado no Plano de Regeneração do Coberto Vegetal da Guiné. O estudo do material vegetal existente no território e a instalação de vários cajueirais por toda a colónia iniciou-se em 1963 (Sardinha 1993). Dois anos depois, Lains e Silva (1965) recomendou a utilização do cajueiro na recuperação da fertilidade dos solos esgotados pelo cultivo do amendoim, através da sua instalação como espécie florestal. O valor das exportações da castanha de caju foi subindo progressivamente e em 1970 ocupava já a terceira posição, a seguir às do amendoim e do coconote (JIU 1972: 36).

Com o início da luta armada em 1963, a população de Cubucaré dividiu-se entre aqueles que ficaram nas povoações aquarteladas (Bedanda, Cabedú, Cadique, Iemberém, Guiledge) e os que "entraram no mato". Durante os onze anos da luta pela independência, a produção de arroz em sequeiro foi muito reduzida: por um lado, no caso das populações que se encontravam nas zonas libertadas, as queimadas destruiriam em parte o seu lugar de refúgio; por outro, as que se encontravam do lado colonial seriam obrigadas a sair da área protegida pelos quartéis, tornando-se um alvo fácil para o exército do Partido Africano para a Independência da Guiné e de Cabo Verde (PAIGC), que os podia obrigar a "entrar no mato". Assim, as populações refugiadas nas tabancas aquarteladas situadas nas margens de rios (Bedanda, Cabedú, Cadique) dedicaram-se ao cultivo de arroz de bolanha salgada, enquanto que nas tabancas do interior (Iemberém e Guiledge) as populações foram alimentadas pelo exército português. Nas "zonas libertadas", a produção de excedentes de arroz foi mantida e estimulada com o objectivo de assegurar a alimentação dos soldados. Porém, os raides dos aviões e os constantes bombardeamentos dificultavam a execução das operações culturais e 
destruíram parte das infra-estruturas das bolanhas salgadas. De 1963 a 1973 observa-se assim uma redução da área ocupada por bolanha salgada e um incremento na área de mangais (Cassamá 2006: 83).

Comparando os mapas elaborados por Cassamá (2006) para os anos de 1953 e 1973, podemos comprovar que durante a guerra ocorreu uma grande recuperação do coberto florestal (figura 4), induzida sobretudo pela redução substancial da área sujeita a corte e queima, ${ }^{5}$ mas também em parte pela regeneração da vegetação natural dos pomares de coleiras que deixaram de ser desbastados regularmente. Este adensamento da vegetação lenhosa ocorreu essencialmente na área correspondente ao regulado de Guiledge, onde o sistema de produção utilizado até hoje é o de sequeiro.

Após a independência, em 1974, o governo adoptou uma política de centralização da economia, traduzida, entre outros aspectos, na fixação dos preços das produções consideradas estratégicas (arroz, amendoim e coconote) e na obrigatoriedade de troca directa dos excedentes por bens importados nos armazéns estatais (Armazéns do Povo). A política de fixação do preço do arroz (a liberalização total do seu preço só aconteceu em 1989), o limitado montante do crédito concedido para a reabilitação das bolanhas salgadas destruídas durante a guerra e a perda progressiva da capacidade de mobilização da mão-de-obra familiar e de entreajuda ${ }^{6}$ dos chefes dos agregados domésticos após a guerra constituíram desincentivos para a recuperação dos níveis de produção de arroz anteriores a 1963 e reorientaram progressivamente os sistemas de produção para a expansão da área de pomares. Ao contrário dos produtores balantas, muitos produtores das restantes etnias que antes da guerra possuíam bolanhas salgadas foram incapazes de as recuperar, sendo obrigados a optar pela produção de arroz em sequeiro, menos exigente em mão-de-obra em termos de tempo de trabalho e de especialização. No entanto, dado o seu reduzido número, a área por estes desflorestada não se considera significativa.

Terminada a guerra, a produção de cola, banana e, em menor escala, citrinos foi utilizada pelos produtores não balantas como estratégia para adquirir um rendimento monetário necessário à compra de bens essenciais e em alguns casos garantir mesmo a auto-suficiência em arroz, através da troca directa por este cereal com produtores balantas. O desinvestimento na produção de arroz de sequeiro e a progressiva orientação para a fruticultura, em que parte da vegetação natural é mantida nos pomares, explica em grande medida a continuada redução, até 1986, da área correspondente à classe de coberto de savana arbórea e o incremento da de floresta, especialmente visível em toda a zona

5 A pesquisa realizada em 2008 e 2009 (durante cinco meses, em todos os sectores da Guiné-Bissau) revelou que, na perspectiva dos agricultores, este mesmo fenómeno de regeneração da floresta secundária ocorreu por todo o país.

6 Os grupos de trabalho passam a exigir o pagamento em dinheiro em vez da tradicional recompensa em arroz no final da colheita, com o qual os jovens organizavam festas. 
nordeste da península (figura 4). Nesta fase, a desflorestação para a instalação de novos pomares é mínima, visto que o investimento é essencialmente feito nos pomares já existentes no tempo colonial.

Até meados da década de 1980, o escoamento de laranjas e bananas encontrava-se nas mãos de comerciantes ambulantes senegaleses que, de forma irregular e altamente desvantajosa para os produtores, se deslocavam a Cubucaré. Por seu turno, o escoamento da cola era assegurado por homens de etnia fula vindos da região Leste (Bafatá e Gabú), que migravam para Cubucaré durante a estação seca à procura de trabalho. Colaboravam na desmatação dos pomares e na desflorestação para cultivo de arroz de sequeiro contra um pagamento em cola, que depois vendiam na sua região com grande lucro, após o que compravam bens essenciais que de novo vinham trocar por cola em Cubucaré. Foi este o contexto em que seria criada a primeira associação de fruticultores - em 1984 - com o objectivo de fomentar a fruticultura, escoar os excedentes de produção e abastecer a região em bens de consumo corrente e que, devido aos apoios internacionais que obteve, deu um impulso extraordinário à expansão da fruticultura na região, reforçado com a liberalização da economia. Após 1985, assiste-se assim a uma vaga de desbaste da floresta aberta para instalação de pomares, mais evidente na zona nordeste da península (figura 4, mapas de 1986 e 1994).

O Programa de Ajustamento Estrutural (1986) teve como consequência, segundo alguns autores, um aumento quase imediato da produção de arroz e de caju (Lea et al. 1990: xi), motivado pela subida dos preços no produtor. Porém, o volume das importações de arroz sobe igualmente de forma notória, em parte devido ao regime de troca obrigatória por caju, cuja cotação subiu em meados da década de 1980 (Dias 1990: 10). Paralelamente, os circuitos de comercialização continuam deficientes e os excedentes de arroz produzidos no Sul do país não são escoados (Fonseca 1988: 15; Imbali 1992: 21). Pesem embora estes factos, comparando os mapas de 1986 e 1994 da figura 4 constata-se que a liberalização dos preços do arroz se vai traduzir num aumento das áreas ocupadas por bolanha salgada nas margens do rio Cumbidjã (ver também Cassamá 2006: 83, figura 33).

A política de incentivo à produção de caju, a sua troca forçada por arroz e a subida do preço da castanha no mercado internacional em meados da década de 1980/inícios da de 1990 deram origem a uma multiplicação dos cajueirais em todo o país e à sua instalação frequente em solos aptos para outras culturas (Fonseca 1990: 17). Em Cubucaré, todavia, só a etnia balanta respondeu de imediato, instalando pomares nas zonas de savana herbácea e arbustiva, em especial na faixa costeira ao longo dos rios Cumbidjã e Balana. A maior plantação de cajueiros existente em Cubucaré até hoje - conhecida localmente por "Ponta do Vitório" ou "S. Francisco da Floresta" - foi instalada a partir de 1985 numa concessão de 1200 hectares da Diocese de Bissau (Handem, cit. em Frazão-Moreira 1999: 456-457) e localiza-se no cruzamento da estrada 

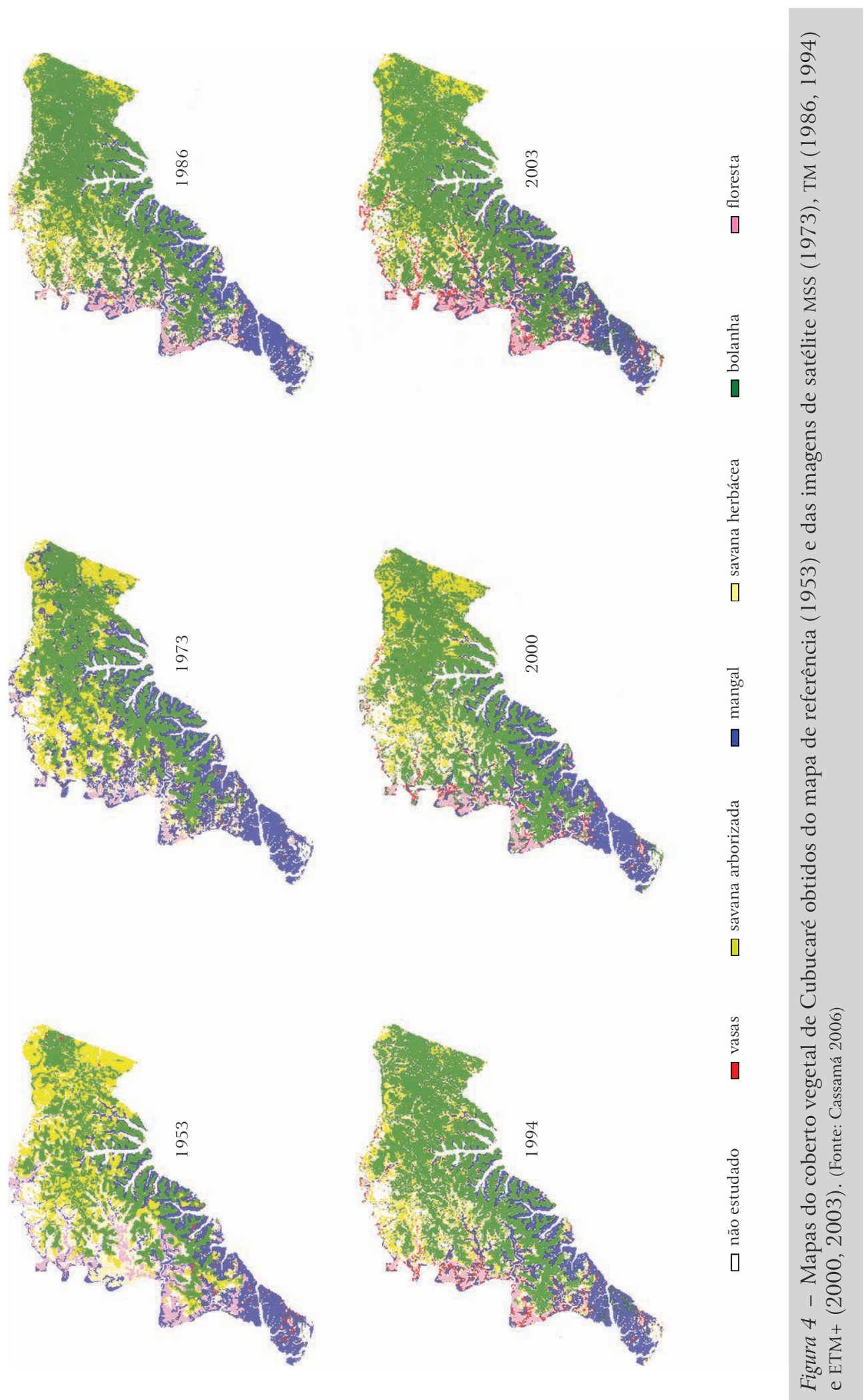
Cabedú-Guiledge com a de Bedanda. Pelo contrário, os pomares dos pequenos agricultores raramente ultrapassam um hectare (Luís Catarino e Viriato Cassamá, comunicação pessoal 2006).

Entre os muçulmanos, o cultivo de caju esteve proibido por razões religiosas ${ }^{7}$ até meados dos anos 90, altura em que a insegurança fundiária gerada pelo início da discussão sobre a nova "lei da terra" e por um projecto de criação de um parque natural desencadearam um processo de apropriação fundiária em zonas de floresta aberta, como adiante se verá. Com efeito, os cajueiros são um marcador ideal de ocupação do solo, em virtude da sua fácil propagação, do seu rápido crescimento e rusticidade e da sua resistência ao fogo. Porém, só em casos raros os agricultores procederam a uma subsequente desflorestação total, necessária à instalação do pomar, realizando unicamente um desbaste da vegetação natural num círculo de cerca de meio metro em torno dos pés de caju. Os pomares de caju instalados em floresta surgem ironicamente na aldeia de Iemberém, onde as ONG que trabalham na região possuem a sua sede local.

O desenvolvimento da fruticultura, com destaque para a banana, está também relacionado com uma redução das áreas desflorestadas para a produção de arroz de sequeiro. Face ao absentismo crescente dos jovens, os produtores mais idosos encaram a fruticultura como um seguro de velhice, porque, nas palavras de um deles, "mesmo que os filhos se vão todos embora, nós podemos continuar a comer com o seu rendimento". Nos pomares tradicionais as árvores de grande porte consideradas úteis são preservadas e a densidade de plantação, conjuntamente com a consociação de espécies de portes diferentes, produzem um ecossistema favorável à manutenção da fertilidade do solo e à redução do ataque de pragas e doenças. Paralelamente, na instalação de pomares de espécies perenes, as bananeiras são usadas durante os primeiros anos para ensombrar as jovens plantas - evitando a rega - e ainda porque a sua produção cobre as despesas da desmatação bianual do pomar até as outras fruteiras entrarem em produção. Esta estratégia produtiva e as técnicas a ela associadas deram origem, a partir de finais da década de 1980, a fases alternadas de aumentos e diminuições localizados no tempo e no espaço das classes de savana arborizada, floresta aberta e floresta densa, mais visíveis na zona Nordeste da península, em especial no regulado de Guiledge (ver Cassamá 2006: 83 e figura 32). Os pomares maduros dão origem a uma leitura espectral nas imagens Landsat, correspondente às classes de floresta densa ou aberta (Cassamá 2006: 98), dependendo da espécie predominante, da densidade de plantação usada e ainda da preservação ou não de espécies arbóreas da vegetação natural.

7 Esta interdição assentava no facto de a partir do sumo do falso fruto se fabricar uma bebida alcoólica e os mais velhos temerem que as mulheres se deixassem tentar, trocando-a por arroz com produtores balantas. 
A expansão da fruticultura, particularmente da produção de banana, está a afastar cada vez mais os pomares das povoações, que hoje se encontram por vezes a vários quilómetros de distância. Sergent (1991: 20) registou já esta tendência, afirmando que se os pomares em 1989 se encontravam a uma distância compreendida entre quatrocentos metros e um quilómetro, em 1991 essa distância era já de mais de dois quilómetros. Este afastamento torna cada vez mais difícil a vigilância dos pomares, sendo enormes as perdas provocadas pelo ataque de pragas (macacos e porcos selvagens), que no caso da banana chegam a destruir completamente um pomar num único dia. Se alguns produtores optam pelo abandono dos pomares de bananeiras mais distantes, a maioria vai aumentando anualmente as áreas, instalando os pomares em zonas de forte concentração de produtores. Esta estratégia é justificada pela menor proporção do prejuízo em relação à produção total. Existe assim um conflito entre a protecção da fauna selvagem e a protecção das florestas, na medida em que a ausência de um controlo sobre as populações de certas pragas obriga a um aumento das áreas desflorestadas para a instalação de pomares. Porém, nenhuma intervenção externa teve em conta este facto.

A partir de 1992, uma ONG local fomentou a introdução de pomares de mangueiras melhoradas, com base na existência de um suposto mercado europeu, no âmbito do projecto mencionado de protecção das florestas e criação de um parque natural. Para ter acesso a crédito, material vegetal melhorado e utensílios de trabalho, os produtores beneficiários deveriam proceder à desflorestação integral do campo, plantar em linhas com um compasso mais alargado do que o usado tradicionalmente - estando ainda interdita a consociação com outras espécies de fruteiras -, regar nos primeiros anos e consociar as mangueiras com amendoim, feijão e mandioca (AD 1995: 2). As técnicas de instalação do pomar preconizadas pelos agentes externos entravam assim em contradição com as técnicas agroflorestais tradicionais, as quais numa perspectiva agroecológica parecem estar mais adaptadas às condições locais e à necessidade global de manter estável, ou mesmo de incrementar, o potencial de sequestro de carbono.

Da análise da distribuição do povoamento (figura 3) ressalta que as aldeias mais populosas (Caboxanque, Bedanda, Cafine, Cabedú, Darsalam, N'cala), todas localizadas nas margens do rio Cumbidjã, são também aquelas onde a produção de arroz em solos de mangal é mais elevada e a etnia balanta é dominante. É também a zona onde, desde os anos 20 do século passado, ocorreu um maior crescimento populacional devido à imigração. Pelo contrário, as margens do rio Cacine, onde os solos são menos propícios ao cultivo do arroz de bolanha salgada, encontram-se fracamente povoadas e é nelas que se situam as principais manchas de floresta densa sub-húmida. No mapa de 1953 observa-se uma grande extensão de área coberta por savana arborizada nas margens do rio Cumbidjã, relativamente à área observada por imagem de satélite em anos subsequentes (figura 4). Informações recolhidas localmente, 
junto de interlocutores com mais de 70 anos, confirmam a existência desde tempos longínquos (anteriores à ocupação colonial administrativa da península e ao aumento da densidade populacional devido à imigração) duma vasta zona de savana herbácea (lala de palha) e arbóreo-arbustiva (lala de mato). Esta ter-se-ia vindo a reduzir ("o mato comeu a lala"), face, segundo os agricultores, a transformações da bacia hidrográfica ("à medida que a água entrou, o mato avançou") e a possíveis mudanças na ecologia da vegetação induzidas pelo cultivo do amendoim durante a época colonial por imigrantes sazonais manjacos. Cumulativamente, esta é também a zona onde se localiza actualmente a grande maioria dos pomares de caju, o que tem vindo a contribuir recentemente para um adensamento da vegetação lenhosa na zona de savana herbácea e arbórea-arbustiva.

Os factos enumerados convergem para duas conclusões: por um lado, o sistema de produção adoptado e as oportunidades de mercado, mais do que o crescimento da população, têm vindo a determinar a pressão sobre os recursos florestais; por outro, a agricultura itinerante não é, desde o início da guerra anticolonial, uma causa importante de desflorestação.

\section{NOVAS DINÂMICAS DE APROPRIAÇÃO DA NATUREZA: UM PATRIMÓNIO PARA QUEM?}

A compreensão do declínio da capacidade reguladora do sistema local de gestão dos recursos naturais só se torna possível através da adopção de uma abordagem histórica que torne visível a sequência de factores que actuaram neste sentido. A conversão à religião islâmica conduziu a um progressivo abandono das práticas "animistas", muitas delas rodeadas agora de grande sigilo, determinando o início da destruição da crença no sistema de mitos e tabus que mantinham a autoridade dos "donos do chão" na regulação do acesso aos recursos naturais nos regulados de Cadique e de Cabedú (ver Temudo 1998, vol. I: 45 1-463). Mais do que um conflito religioso, trata-se de um conflito político pela hegemonia do território e o controlo dos seus recursos.

A religião tem vindo a servir às etnias mais islamizadas como uma arma política para reduzir a hegemonia nalu sobre o território, hegemonia essa que, como atrás referido, advém dos contratos estabelecidos com os iras "donos do chão", cujos laços devem ser renovados de acordo com um calendário ritual e seguindo determinadas práticas, uma das quais completamente interdita pela religião muçulmana (libações com bebidas alcoólicas). O islamismo deu origem ainda a uma procura de bem-estar e de riqueza material e a um maior individualismo, contrário ao espírito de gestão comunitária e sustentada dos recursos naturais da etnia nalu.

A partir de 1963, a luta armada veio introduzir um vector de mudança de importância determinante no sistema local de gestão dos recursos naturais. 
Com efeito, as florestas mais densas, às quais o acesso era até aí limitado, foram o refúgio da população que se encontrava do lado do PAIGC. Por esse motivo, foram realizadas determinadas cerimónias, de forma a levantar as sanções rituais que impediam o acesso livre às zonas-tampão.

Após a independência, a terra foi nacionalizada e o poder das autoridades tradicionais desautorizado. Em sua substituição são nomeados representantes do Estado. Porém, o sistema estatal de guardas florestais é totalmente ineficaz, dado o reduzido número de guardas, a falta de meios de transporte e o baixo salário, que os torna facilmente subornáveis. O facto de a terra passar a ser considerada propriedade do Estado reforça os efeitos da islamização crescente sobre o sistema de gestão nalu, impedindo os "donos do chão" de executar os rituais que interditavam o acesso livre aos recursos naturais dos "matos malgosse" e zonas-tampão, dado que poderiam ser acusados de feitiçaria. Muito embora o sistema de mitos e tabus tenha continuado a funcionar de forma relativamente eficaz até à década de 1990, a independência veio assim criar espaço para o início de um conflito intra e interétnico e institucional (instituições locais versus externas).

Em 1994, as primeiras eleições multipartidárias trouxeram uma nova palavra de ordem - "democracia" -, utilizada pelas restantes etnias para contestar a hegemonia nalu na gestão dos recursos naturais. Se na aparência é mantido um respeito pelos nalus como "donos do chão", desenvolve-se gradualmente um conflito interétnico de baixa intensidade que tenta transformar um sistema de acesso regulado a áreas de usufruto comum num sistema de acesso aberto. Em paralelo, a crescente integração no mercado veio também reforçar o conflito intergeracional, mais do que o próprio conflito interétnico. Se os mais velhos subordinavam as estratégias imediatas às estratégias de longo prazo - que asseguravam a reprodução económica, social e cultural do grupo -, os jovens reduzem o futuro ao momento presente e à sua própria pessoa, desafiando todos os mitos e tabus na procura de uma riqueza imediata.

Para os nalus, a floresta é percebida na sua dimensão sagrada, mas também como um reservatório de recursos naturais. Por este motivo, a sua percepção da diminuição progressiva das áreas-tampão, que rodeiam os locais de culto dos iras "donos do chão", tem motivado, por um lado, uma redução da dimensão das parcelas de cultivo atribuídas aos novos habitantes e, por outro, um controlo mais rígido das transmissões para fora dos agregados domésticos a quem grandes parcelas de terra tinham sido distribuídas. Se, anteriormente, qualquer agregado que abandonasse a região podia oferecer o seu fundiário, bastando para tal informar os "donos do chão", agora estes decidem pela sua divisão por forma a beneficiar um maior número de requerentes. Esta percepção da necessidade de proteger os recursos naturais ainda existentes é sentida com maior intensidade pela geração mais velha - com mais de 50 anos -, 
aquela cuja islamização foi menos profunda e cujos valores ainda não estão tão marcados por novas necessidades de consumo.

Em meados da década de 1990, a insegurança fundiária criada pelo anúncio da elaboração de uma nova "lei da terra" 8 - da qual os agricultores ouvem falar através dos parentes que vivem na cidade - desencadeou diversas estratégias: divisão das reservas fundiárias das povoações; divisão nominal, por herança antecipada, dos terrenos de cada agregado doméstico pelos filhos do sexo masculino; plantação de cajueiros em terrenos em pousio prolongado; registo dos pomares adquiridos por compra pelos jovens. Após a liberalização económica, houve uma corrida da elite política e económica ao registo de grandes concessões de terreno - por forma a garantirem o acesso às linhas de crédito recentemente abertas -, dando origem a numerosos conflitos com os pequenos agricultores em outras partes do país (Bruce, Moura e Tanner 1992; Tanner 1991). O início da discussão da lei da terra vem assim criar, entre os agricultores de Cubucaré, o medo de que as suas reservas de fundiário e terrenos em pousio possam vir a ser apropriados pelo Estado.

De todos os factores que na década de noventa tiveram um impacte negativo no sistema tradicional de gestão de recursos naturais, foi precisamente um projecto implementado por três ONG locais o que desencadeou mais conflitos e estratégias de segurança fundiária (Temudo 2005). O seu objectivo era "a salvaguarda da Mata de Cantanhez com a plena participação das organizações de base e dos agricultores" (AD 1993: 2). Repare-se que, tanto neste como em outros documentos (e.g. Schwarz 1995: 20, 22; AD 1992: 10; AD et al. 1992: 4), não se faz referência aos "donos do chão" - cujo sistema de gestão dos recursos naturais preservou as florestas até hoje -, e que se nomeia em primeiro lugar as associações e agrupamentos, instituições introduzidas pelos agentes externos, de representatividade muito limitada face ao conjunto das sociedades e cuja relação das direcções com os restantes membros é em muitos casos conflituosa, dada a falta de transparência na gestão (Temudo 1998, vol. II: 95-1 10).

A estratégia de acção do projecto considera conciliáveis medidas de "repressão" (legislativas e administrativas), a implementar de imediato, e "a participação das populações em todas as etapas do processo", conseguida através de soluções a encontrar a médio/longo prazo (AD et al. 1992: 28). Pretende-se "reabilitar, rever e reactualizar os diplomas legislativos elaborados nos anos 50, que definem a Mata de Cantanhez como uma reserva integral" (AD et al. 1992: 29).

No documento do projecto é afirmado que o cultivo de arroz em sequeiro cujo ritmo de itinerância se diz ter vindo a aumentar - e a fruticultura constituem mecanismos de desequilíbrio ecológico (AD et al. 1992: 20), omitindo que 1998. 
foi precisamente a fruticultura que deu origem a uma redução da área anual dedicada a corte e queima e que contribuiu mesmo para um aumento significativo do coberto vegetal lenhoso. Por outro lado, é sobrevalorizada a hipótese de substituição do cultivo de arroz de sequeiro pelo de bolanha doce (AD et al. 1992: 30), técnica que os agricultores só usam em anos de crise alimentar pelas suas desvantagens comparativas (ver Temudo 1998, vol. I: 148, 149).

As ONG tentam contrariar uma estratégia de ocupação do espaço que responde a um problema de incerteza face às condições aleatórias do clima, às condições actuais de acesso à mão-de-obra, às grandes perdas anteriores e posteriores à colheita, ao funcionamento do mercado, ao crescimento demográfico e à futura aplicação de uma nova "lei da terra", sem no entanto apresentarem alternativas viáveis do ponto de vista económico. Pelo contrário, o projecto investiu essencialmente em acções conducentes a um melhor conhecimento da biodiversidade do meio, ao ordenamento do território e consequente demarcação dos maciços florestais e em acções de informação e sensibilização da opinião pública - seminários, encontros, brochuras, exposições fotográficas, concursos escolares, produção de filmes e visitas de estudo -, destinadas essencialmente à população urbana e a promover a imagem das ONG junto dos financiadores (Temudo 1998, vol. II: 110-120).

As manchas florestais delimitadas pelo projecto excedem as áreas dos antigos "matos malgosse" e zonas-tampão, criando um profundo mal-estar entre a população (Temudo 2005), que vê reduzido o seu acesso aos recursos e as compensações prometidas/esperadas circunscritas a um número restrito de produtores. Um dos pontos fortes da contestação residia no argumento de que, se as florestas existiam no momento da elaboração do projecto, seria porque a própria população as tinha conservado, como ilustram as seguintes declarações de alguns entrevistados: "Desde os nossos pais que há matos que a população nunca desmatou"; "Nós não precisamos que nenhum projecto nos venha dizer para guardarmos o mato. Se eles quando chegaram viram os matos aqui, foi porque nós os guardámos desde o tempo dos nossos avós". A manutenção, até 2003, dos limites dos grandes maciços de floresta densa sub-húmida (que correspondem às florestas sagradas e zonas-tampão) foi, com efeito, comprovada por Cassamá (2006) com recurso a fotografia aérea, a imagens de satélite e a observação directa no terreno. De salientar ainda que os maciços florestais delimitados na área do futuro Parque Nacional das Matas de Cantanhez se localizam na totalidade fora do regulado fula de Guiledge (ver Cassamá 2006: 18), único regulado de Cubucaré onde não é aplicado o sistema tradicional nalu de gestão dos recursos naturais.

A nomeação de guardas de várias etnias veio agravar os conflitos interétnicos e dar origem a uma tensão no seio da própria etnia nalu, dado que nem os guardas desta etnia foram nomeados pelos "donos do chão". A oferta de uma bicicleta, a promessa de possíveis remunerações pagas por hipotéticos turistas 
e a esperança de, no futuro, conseguirem exigir do projecto o pagamento de um salário - a sua principal reivindicação nas reuniões de negociação - explicam a aceitação do cargo.

A livre entrada nos "matos", outrora considerados malgosse, dos técnicos do projecto e de investigadores, financiadores e avaliadores - "os brancos" -, em simples visitas ou em missões de estudo para as quais não é pedida autorização aos "donos do chão", vem criar a ideia nas restantes etnias de que "os nalus venderam os matos aos brancos". Paralelamente, os nalus não compreendem qual a razão da escolha das suas florestas pelo projecto - havendo outras na Guiné-Bissau -, suspeitando que se trataria de uma tentativa para lhes roubar os iras. Agentes externos e financiadores são acusados de, através do projecto, tentarem estabelecer contratos com os iras para os levarem consigo. Esta percepção está enraizada na crença local de que os iras são a fonte de todo o poder, riqueza e sabedoria para aqueles que estabelecem contratos preferenciais com eles. Nesta medida, o projecto foi um factor decisivo no processo de destruição do conjunto de mitos e tabus que sustentam o sistema local de gestão dos recursos naturais - sem os iras que os guardam, o acesso aos recursos dos matos passa a ser livre (Temudo 2005). A revolta da população contra o projecto desencadeou ainda um movimento de desflorestação ao longo das estradas no regulado de Cadique (onde a sede das ONG se situava) e um reforço das estratégias de segurança fundiária utilizadas face às possíveis consequências da futura "lei da terra". O projecto acabaria, no entanto, por ter fim em 1997, devido a desentendimentos entre as próprias ONG.

Em 1998, a representação permanente da União Internacional para a Conservação da Natureza (UICN) na Guiné-Bissau desenvolveu esforços para dar continuidade ao projecto anterior (UICN 2000: 1). Porém, a guerra civil de 1998/99 interrompeu este processo e contribuiu para novos desenvolvimentos na relação da população de Cubucaré com a floresta. $\mathrm{O}$ facto de se tratar de uma guerra marcadamente urbana provocou um movimento de mais de 200 mil deslocados para as zonas rurais, que aí se refugiaram durante os onze meses que ela durou. Em Cubucaré, um grande número de agregados domésticos recebeu deslocados de guerra (Temudo e Schiefer 2003: 405). A maioria dos deslocados não participou nos trabalhos agrícolas em 1998, mas em 1999, já após o fim da guerra, alguns solicitaram campos de cultivo cujos rendimentos levaram consigo para recomeçar a vida em Bissau. O seu número foi porém reduzido, podendo-se afirmar que o impacte sobre a área sujeita a corte e queima foi quase nulo. Por seu lado, os produtores locais também não foram capazes de aumentar os campos de sequeiro por falta de sementes, seja porque uma parte fora consumida pelos deslocados, seja porque a colheita de 1998 fora reduzida devido a uma irregular distribuição das chuvas. As estratégias produtivas a que os agricultores recorreram consistiram, durante a estação seca de 1998, no aumento da produção de raízes e tubérculos (mandioca, batata 
doce, inhame e falso inhame) e, durante a estação das chuvas de 1999, no incremento da produção de cereais mais resistentes à seca (sorgo, milheto e fónio) e no recurso à técnica de sementeira directa de arroz nas bolanhas salgadas, por forma a rentabilizar a quantidade de sementes possuída. A recepção dos deslocados durante a guerra não teve, como tal, um efeito negativo em termos de desflorestação de novas áreas.

As florestas voltam a ser relembradas como lugares de refúgio e como lugares sagrados, morada de iras, e estes são de novo convocados para proteger o território, através da execução de cerimónias destinadas a "fechar o chão" em relação à guerra. Com o fim do conflito, a vitória eleitoral de um partido maioritariamente balanta veio introduzir uma alteração na relação de forças e uma crescente perda de autoridade dos "donos do chão" - fragilizada já pelo projecto acima referido -, com consequências gravosas em termos da gestão dos recursos naturais. Por este motivo, quando os técnicos da UICN abordaram os régulos nalus para os auscultar acerca da implementação de um novo projecto para a conservação das florestas de Cantanhez, ${ }^{9}$ a iniciativa foi bem recebida: num contexto em que o Estado era percebido como tomando o partido dos infractores, as ONG mandatárias de um poder que vinha "mais de cima" - a "Terra de Branco" - surgiam como o último recurso. Em 2002, sob proposta da UICN, assistiu-se a novas mobilizações para a reeleição de "comités de gestão" e de "guardas dos matos". Foram então seguidas as já conhecidas recomendações e expectativas dos agentes externos - nomeando guardas de diferentes etnias -, numa tentativa de voltar a atrair "projectos" para a região, dado que a estrada que os une a Bissau necessitava de reparação urgente. Porém, desta vez, os jovens, considerando que os "régulos" se deixam comprar pelos agentes externos, aceitando decisões que os prejudicam directamente e à região (em troca de benefícios pessoais), decidem criar a "União dos Comités de Co-Gestão dos 15 Matos Reservados de Cantanhez": se os "brancos" e as ONG locais consideram que as suas florestas têm valor, então terão de os compensar devidamente para que elas sejam preservadas. Qual será o valor que o seu "património sagrado" alcançará como "património mundial" no mercado da ajuda ao desenvolvimento? Por fim, o liberalismo triunfa e as florestas parecem estar a libertar-se do seu valor simbólico para se tornarem uma mercadoria no ecomercado mundial.

9 Em 2000, a UICN elaborou uma proposta de gestão e de classificação dos maciços de floresta sub-húmida de Cantanhez como área protegida (UICN 2000), e em 2004 um conjunto de técnicos identificou as futuras zonas de conservação, definindo como critérios que presidiram à sua selecção: a diversidade de mamíferos, presença de mamíferos raros e de répteis pouco estudados, existência de corredores transfronteiriços de fauna grossa rara ameaçada, diversidade e abundância de aves aquáticas, riqueza piscícola do rio Cacine, presença de espécies vegetais raras nas últimas florestas sub-húmidas do país e de florestas de mangal ameaçadas (Simão et al. 2004). 
CONCLUSÕES: PATRIMONIALIZAR A NATUREZA, PRODUZIR A CRISE AMBIENTAL

O conhecimento do impacte de factores como o crescimento da população, diferentes regimes de posse e uso da terra e de gestão dos recursos naturais, diferentes sistemas de sustento e políticas económicas, e ainda alterações climáticas sobre mudanças no uso dos recursos naturais e na biodiversidade é ainda muito reduzido, tornando necessária a aplicação de abordagens inovadoras. Nesta medida, os crescentes estudos que têm vindo a aliar técnicas etnográficas e/ou sociológicas e de detecção remota (e.g. Amanor e Pabi 2007; Evans e Moran 2002; Sussman, Green e Sussman 1996; Guyer e Lambin 1993) permitiram uma análise mais holística e descodificar conexões inesperadas entre as variáveis consideradas.

Na região de Cubucaré, o sistema de gestão nalu dos recursos naturais emerge como a principal variável explicativa da preservação até hoje dos grandes maciços de floresta densa sub-húmida dos regulados de Cadique e de Cabedú. Considerando que os matos sagrados existentes na época pré-colonial coincidem, de acordo com a tradição oral, com os encontrados actualmente, podemos com alguma segurança afirmar que as maiores manchas florestais se concentravam na faixa costeira ao longo das margens do rio Cacine. A estabilidade nos limites destes matos, observada por Cassamá (2006), faz-nos pensar que a baixa densidade populacional da zona terá também influído na sua preservação, dado que os matos situados na zona mais interior da península - sujeitos a uma maior pressão antrópica em virtude do maior número de habitantes e do sistema de produção praticado - têm sofrido progressivas reduções das zonas-tampão. A zona de maior pressão demográfica - faixa costeira ao longo das margens dos rios Cumbidjã e Balana - é também aquela em que o sistema de produção assenta exclusivamente na utilização do mangal (bolanha salgada) e das savanas (pomares de caju). A inexistência de manchas florestais densas no regulado de Guiledge, observada já no mapa de 1953, deve-se, de acordo com os mais velhos nalus, à sua destruição pela etnia fula. Os fulas, sem qualquer relação sagrada com a floresta, praticando um sistema de produção itinerante de corte e queima e utilizando os fogos descontrolados na agricultura e na caça, terão progressivamente aumentado a área ocupada por savana nesta região.

As sucessivas expansões e retracções do mercado corresponderam a mudanças vincadas no coberto vegetal de Cubucaré. Associada ao período mais intenso de retracção do mercado, a guerra anticolonial constituiu a época em que ocorreu uma menor pressão antrópica sobre as florestas e um correspondente incremento da pressão sobre os mangais em certas zonas da península. O mercado iria de novo desempenhar um papel preponderante após a independência, ao provocar a reorientação de um sistema de produção centrado no arroz (destinado a autoconsumo e venda) para um outro que assenta numa 
crescente produção de fruteiras para venda e na compra do cereal importado. A mão-de-obra jovem vai-se progressivamente desviando da produção agrícola para as actividades comerciais e a maior densidade demográfica (resultante do crescimento populacional e da imigração) não correspondeu a uma proporcional pressão sobre as florestas. Em síntese, contrariando a narrativa neomalthusiana da degradação ambiental, o crescimento demográfico ocorrido nas últimas cinco décadas não deu origem a uma redução da área coberta por floresta e a um processo de savanização crescente, nem contribuiu para uma estagnação/diminuição da produção agrícola.

Este estudo de caso ilustra também a flexibilidade e a adaptabilidade das leis consuetudinárias nalus que regulam a gestão dos recursos naturais - leis essas que assentam num princípio de equidade social, que garante a todos os habitantes o direito de prover à sua subsistência, e na interdição da venda da terra -, mas também a sua fragilidade num condicionalismo de crescente islamização, individualismo e desautorização externa. A sacralidade da natureza, que permitiu a preservação dos grandes maciços de floresta densa sub-húmida até aos nossos dias, foi irreversivelmente ferida pelas intervenções de desenvolvimento (lei da terra e projecto de criação de um parque natural), que curiosamente tinham por objectivo defendê-los contra a suposta acção predatória das populações locais.

O projecto de criação do parque natural de Cantanhez surge assente na construção de um falso problema, existente numa falsa região. ${ }^{10}$ Como vimos, até ao início do projecto, os grandes maciços florestais tinham sido preservados e a maior pressão exercida por uma população crescente sobre os recursos naturais deu origem a alterações nas regras de atribuição de fundiário e a uma extraordinária inovação nos sistemas de produção (na qual também influíram alterações nas relações sociais e nas políticas económicas). A insegurança gerada pela ameaça que representava a "lei da terra" iria reflectir-se numa estratégia de ocupação permanente (com fruteiras lenhosas) das reservas de fundiário de cada agregado doméstico, sem atingir os grandes maciços florestais. Malaise (1996: 72) - um reputado botânico belga que tem vindo a colaborar com as ONG guineenses que intervêm na região em estudo, através da realização de numerosos estudos -, citando o Plano Director Nacional Florestal de 1992, afirma ter ocorrido uma diminuição da área ocupada pelas florestas densas sub -húmidas (correspondentes às florestas sagradas e zonas-tampão) de Cubucaré de 177.500 hectares em 1978, para 135.431 hectares em 1985. É curioso notar que é exactamente até meados dos anos 80 que o coberto florestal de

10 James Ferguson (1994) demonstrou - com um estudo de caso no Lesoto - que as organizações de desenvolvimento criam o seu próprio discurso, construindo uma "estrutura de conhecimento" da realidade sobre a qual vão intervir que tem importantes consequências sociais, apesar do frequente insucesso dos projectos em termos dos seus objectivos declarados. 
Cubucaré apresenta um crescimento continuado - dado que só a partir dessa época se inicia o processo de desflorestação para a instalação de novos pomares -, e que o investigador não questiona a validade destes dados com base na sua extensa pesquisa de campo, o que demonstra como o sistema de valores se sobrepôs à análise empírica.

Mas a própria delimitação da região (e concomitantemente do problema que a acção de desenvolvimento tenta resolver) assenta num erro. As famosas matas de Cantanhez, sobre as quais se interessou a administração colonial e que o projecto pretende proteger, estão situadas em que território? O território de Cantanhez é uma construção colonial (ver Frazão-Moreira 1999: 46), que corresponde ao actual regulado de Cadique. É precisamente neste território que existem ainda hoje as maiores florestas densas sub-húmidas, cujos limites foram preservados através do sistema nalu de gestão dos recursos naturais. Ao fazer coincidir os limites de Cantanhez com os de toda a península de Cubucaré, o projecto construiu artificialmente o problema da destruição dos "matos" em zonas onde eles talvez nunca tivessem existido ou onde a sua destruição ocorreu bem no início da ocupação colonial (caso do regulado de Guiledge).

Se a Convenção do Rio (1992) coloca a manutenção da biodiversidade no centro das preocupações mundiais, o protocolo de Quioto (1997) recoloca o problema, já que as alterações climáticas nos obrigam a enquadrar a questão da biodiversidade numa perspectiva ecológica mais abrangente. Nesta medida, a gestão dos recursos naturais pelas populações de Cubucaré parece consentânea com as preocupações actuais, pela dupla intervenção na protecção dos grandes maciços florestais e pela activa e continuada substituição de um sistema de produção consumidor de floresta por um outro mais diversificado e que se baseia na plantação de árvores fruteiras. Desta forma, a estratégia local consegue também aliar com sucesso o desenvolvimento económico e a conservação do meio ambiente.

Os conflitos entre diferentes actores locais e entre estes e actores externos que tentam introduzir novas práticas de conservação dos recursos naturais emergem, na maioria dos casos, de diferenças em termos de conhecimentos, práticas, percepções e representações sobre a natureza (e.g. Temudo 2005). Frequentemente, as populações locais têm sido consideradas responsáveis pela degradação ambiental, do que resulta a adopção de abordagens conservacionistas biocêntricas. Pelo contrário, as abordagens assentes no princípio do "desenvolvimento comunitário" e a ideia de que o desenvolvimento económico nem sempre é adverso à conservação da natureza têm também sido criticadas pela sua falta de eficiência (e.g. Oates 1999). O caso aqui em estudo é um bom exemplo de como as abordagens de "desenvolvimento comunitário" têm promovido uma ideia corporativa e homogénea de "comunidade", subalternizando as constelações de poder e os conflitos que estas encerram. Ao deslocar 
o centro de poder da instituição tradicional gerontocrática e monoétnica dos "donos do chão" para as organizações, criadas exogenamente "de cima para baixo", dos "guardas de matos" e "comités de gestão" interétnicos e constituídos maioritariamente por jovens, a intervenção externa não conduz a uma melhor e mais democrática gestão dos recursos naturais, mas à transformação de um sistema equitativo de acesso aos recursos e de gestão sustentável num sistema que vai abrir as portas à "pilhagem" dos recursos - "a tragédia dos comuns", para relembrar Hardin (1968).

Em síntese, torna-se necessário olharmos para além do território e da escassez de recursos, por forma a identificarmos "a construção social, cultural e política dos territórios através da qual a competição pelos recursos ocorre e os sistemas de sustento operam" (Gausset e Whyte 2005: 8), e compreendermos adequadamente os múltiplos factores sociais e biofísicos que determinam as interacções entre população, agricultura e ambiente.

\section{BIBLIOGRAFIA}

AD, 1992, Relatório e Contas da Direcção do Exercício de 1991-92. Bissau, Acção para o Desenvolvimento.

—, 1993, Projecto Integrado de Cubucaré: Relatório de Actividades de 1992. Bissau, Acção para o Desenvolvimento.

—, 1995, PIC: Rapport d'activités de 1994. Bissau, Acção para o Desenvolvimento.

AD, et al., 1992, Salvaguarda das Últimas Florestas Primárias Sub-húmidas da Guiné-Bissau: Documento de Projecto (1992-1994). Bissau, Acção para o Desenvolvimento, Tiniguena e Alternague.

Álvares De ALMADA, André, 1964 [1594], Tratado Breve sobre os Rios de Guiné do Cabo Verde. Lisboa, Editorial LIAM.

AMANOR, Kojo, e Opoku PABI, 2007, "Space, time, rethoric and agricultural change in the transition zone of Gana”, Human Ecology, 35: 51-67.

ANGINOT, Etiènne, 1988, Approche de la diversité des systèmes agraires du secteur de Bedanda. Montpellier, CNEART, EITARC, EDI, IRFED.

—. 1989, Análise da Diversidade dos Sistemas de Produção: A Zonagem. Metodologia e Estudo de Caso na República da Guiné-Bissau. Bissau, DEPA, EDI-IRFED.

BOSERUP, Ester, 1965, The Conditions of Agricultural Growth: The Economics of Agrarian Change under Population Pressure. Londres, Allen and Unwin.

—, 1981, Population and Technology. Oxford, Basil Blackwell.

Brockington, Dan, 2002, Fortress Conservation: The Preservation of the Mkomazi Game Reserve, Tanzania. Oxford, James Currey. 
BRUCE, John, Alexandrina MOURA, e Christopher TANNER, 1992, Uma Nova Lei da Terra para a Guiné-Bissau: Necessidades e Oportunidades. Um Relatório Preparado para a USAID Guiné-Bissau. Madison, University of Wisconsin, Land Tenure Center.

BURNHAM, Philip, 2000, "Whose forest? Whose myth? Conceptualizations of community forests in Cameroon”, em Allen Abramson e Dimitrios Theodossopoulos (eds.), Land, Law and Environment: Mythical Land, Legal Boundaries. Londres, Pluto Press, 31-57.

CARREIRA, António, 1962, "População autóctone segundo os recenseamentos para fins fiscais: circunscrição civil de Catió e Gabú”, Boletim Cultural da Guiné Portuguesa, 17 (66): 221-280.

CARVALHO, Joaquim, 1949, "Nota sobre a distribuição e história dos povos da área do Posto de Bedanda", Boletim Cultural da Guiné Portuguesa, 5 (14): 307-318.

CASSAMÁ, Viriato, 2006, Alterações do Coberto do Solo na Mata do Cantanhez (Guiné-Bissau) de 1953 a 2003. Lisboa, Instituto Superior Técnico, dissertação de mestrado.

CERNEA, Michael, e Kai SCHMIDT-SOLTAU, 2006, "Poverty risks and national parks: policy issues in conservation and resettlement", World Development, 34 (10): 1808-1830.

CLEAVER, Kevin, e Gotz SHREIBER, 1994, Reversing the Spiral: The Population, Agriculture and Environmental Nexus in Sub-Saharan Africa. Washington, The World Bank.

DIAS, Nelson, 1990, Produção, Importação e Comercialização de Arroz na Guiné-Bissau. Seminário Nacional sobre Arroz Próspero. Bissau, DEPA.

EHRLICH, Paul, e Anne EHRLICH, 1993, La Explosión Demográfica: El Principal Problema Ecológico. Barcelona, Salvat.

EVANS, Tom, e Emilio MORAN, 2002, "Spatial integration of social and biophysical factors related to land cover change", Population and Development Review, 28: 165-186.

FAIRHEAD, James, e Melissa LEACH, 1996, Misreading the African Landscape: Society and Ecology in a Forest-Savannah Mosaic. Cambridge e Nova Iorque, Cambridge University Press.

FAIRHEAD, James, e Melissa LEACH, 1998, Reframing Deforestation: Global Analysis and Local Realities, Studies in West Africa. Londres, Routledge.

FERGUSON, James, 1994, The Anti-politics Machine: "Development", Depoliticization, and Bureaucratic Power in Lesotho. Minneapolis e Londres, University of Minnesota Press.

FONSECA, José, 1988, "Alguns elementos da estratégia do desenvolvimento agrícola", Boletim de Informação Científica e Técnica, Bissau, 1: 1-19.

—_, 1990, Arroz: Que política? Seminário Nacional sobre Arroz Próspero. Contuboel, DEPA.

FRAZÃO-MOREIRA, Amélia, 1999, A Apropriação Social da Natureza entre os Nalus da Guiné-Bissau: A Etnobotânica num Contexto de Mudança. Lisboa, ISCTE, dissertação de doutoramento.

GAUSSET, Quentin, e Michael WHYTE, 2005, “Introduction”, em Quentin Gausset, Michael Whyte e Torben Birch-Thompsen (eds.), Beyond Territory and Scarcity: Exploring Conflicts over Natural Resources Management. Estocolmo, Nordiska Afrikainstitutet, 7-26.

GUYER, Jane, e Eric LAMBIN, 1993, "Land use in an urban hinterland: ethnography and remote sensing in the study of African intensification", American Anthropologist, 95 (4): 839-859.

HARDIN, Garrett, 1968, “The tragedy of the commons”, Science, 162: 1243-1248.

HUIJSMAN, Bram, e Herman SAVENIJE, 1991, "Making haste slowly", em B. Huijsman e H. Savenije (eds.), Making Haste Slowly: Strengthening Local Environmental Management in Agricultural Development. Amesterdão, Royal Tropical Institute, 13-34.

ICKOWITZ, Amy, 2006, "Shifting cultivation and deforestation in tropical Africa: critical reflections”, Development and Change, 37 (3): 599-626. 
IMBALI, Faustino, 1992, "Um olhar sobre o sistema alimentar balanta: o caso das tabancas de Mato Farroba e Cantone”, Soronda, 14: 3-27.

INEC, 1979, Recenseamento Geral da População de 1979: Resultados Provisórios da Província Sul. Bissau, INEC.

—., 1992, Recenseamento Geral da População e Habitação de 1991: Resultados Preliminares da Província Sul. Bissau, INEC.

INEP/INEC, 2007, Recenseamento e Estudo Sócio-económico e Ambiental das Áreas Protegidas. Bissau, INEP e INEC.

JIU, 1972, Prospectiva do Desenvolvimento Económico e Social da Guiné. Lisboa, Junta de Investigações do Ultramar.

KOTTO-SAME, Jean, et al., 1997, "Carbon dynamics in slash-and-burn agriculture and land use alternatives of the humid forest zone in Cameroon”, Agriculture, Ecosystems and the Environment, 65: 245-256.

LAINS e SILVA, Helder, 1965, "Plano de desenvolvimento da cultura do cajueiro na Guiné Portuguesa”, Comunicações, 49: 19-58.

LEA, J., et al., 1990, Rice Production and Marketing in Guinea-Bissau: A Contribution for Policy Dialogue. Bissau, Food and Feed Grains Institute e INEP.

LEACH, Melissa, e James FAIRHEAD, 2000, "Challenging neo-Malthusian deforestation analyses in West Africa's dynamic forest landscapes", Population and Development Review, 26 (1): 17-43.

—, 2001, "Plural perspectives and institutional dynamics: challenges for local forest management", International Journal of Agricultural Ressources, Governance and Ecology, 1 (3/4): 223-242.

MALAISE, François, 1996, Caractérisations phytogéographique et écologique des forêts de Cantanhez (Région de Tombali, Guinée-Bissau). Bissau, Acção para o Desenvolvimento.

MALTHUS, Robert, 1826 [1798], An Essay on the Principle of Population. Londres, John Murray. OATES, John, 1999, Myth and Reality in the Rain Forest: How Conservation Strategies are Failing in West Africa. Berkeley, University of California Press.

PÉLISSIER, René, 1989, História da Guiné, vol. I. Lisboa, Estampa.

RICHARDS, Paul, 2005, "New war: an ethnographic approach", em Paul Richards (ed.), No Peace, No War: An Anthropology of Contemporary Armed Conflicts. Athens e Oxford, Ohio University Press e James Currey, 1-21.

SARDINHA, Raul, 1993, "O papel da árvore nos sistemas agrários da Guiné-Bissau”, em 1.as Jornadas sobre a Agricultura da Guiné-Bissau: Comunicações. Lisboa, Secretaria de Estado da Ciência e Tecnologia, 183-206.

SCHMIDT-SOLTAU, Kai, 2003, "Conservation-related resettlement in Central Africa: environmental and social risks", Development and Change, 34 (3): 525-551.

SCHWARZ, Carlos, 1995, "Guiné-Bissau: a salvaguarda da mata de Cantanhez", A Rede para o Desenvolvimento Local, 13: 20-25.

SERGENT, Bertrand, 1991, Étude de la filière fruit en Guinée-Bissau et de la production fruitière dans la région de Tombali. Bissau, DEPA-EDI-IRFED.

SILVA, Aristides, Leonardo CARDOSO, e Alfredo Simão da SILVA, 2001, Um Tipo de Área Protegida. Bissau, GPC e UICN.

SIMÃO, Alfredo, et al., 2004, Identificação das Futuras Zonas de Conservação da Área Protegida Transfronteiriça da Guiné - Guiné-Bissau. Bissau, Ministério de Agricultura e Desenvolvimento Rural, UICN. 
SUSSMAN, Robert, Glen GREEN, e Linda SUSSMAN, 1996, "The use of satellite imagery and anthropology to assess the causes of deforestation in Madagascar", em Leslie Sponsel, Thomas Headland e Robert Bailey (eds.), Tropical Deforestation: The Human Dimension. Nova Iorque, Columbia University Press, 296-315.

TANNER, Christopher, 1991, Relations between Ponteiros and Tabancas: Implications for a New Land Law in Guinea-Bissau. Cambridge, SEPR Associates.

TEMUdo, Marina P., 1998, Inovação e Mudança em Sociedades Rurais Africanas: Gestão dos Recursos Naturais, Saber Local e Instituições de Desenvolvimento Induzido. Lisboa, Instituto Superior de Agronomia, dissertação de doutoramento.

— 2005 , "Western beliefs and local myths: a case study on the interface between farmers, NGOs and the state in Guinea-Bissau rural development interventions", em Tim Kersalle e Jim Igoe (eds.), Between a Rock and a Hard Place: NGOs, Donors and the State in Africa. Durham, Carolina Academic Press, 253-277.

TEMUDO, Marina P., e Ulrich SCHIEFER, 2003, "Disintegration and resilience of agrarian societies in Africa: the importance of social and genetic resources. A case study on the reception of urban refugees in the South of Guinea-Bissau", Current Sociology, 51 (3/4): 395-418.

TIFFEN, Mary, Michael MORTIMORE, e Francis GICHUKI, 1994, More People, Less Erosion: Environmental Recovery in Kenya. Nova Iorque, John Wiley \& Sons.

UICN, 2000, Project de conservation des forêts de Cantanhez (Guinée-Bissau): proposition de gestion et de classement en aire protégé des dernières massifs des forêts subhumides. Bissau, UICN.

UNCED, 1992, Rio Declaration on Environment and Development: Earth Summit. Rio de Janeiro, UNCED.

The narrative of environmental degradation in Southern Guinea-Bissau: an ethnographic deconstruction - Marina Padrão Temudo - Instituto de Investigação Científica Tropical, Portugal • marinatemudo@gmail.com

Through a detailed case-study this paper aims not only to unveil the complexity of the relationship among population increase, agriculture and sustainable management of natural resources, but also to reveal the reductionism of the so-called "environmental crises narratives". The paper highlights the methodological and epistemological advantages of linking ethnographic field research with remote sensing and geographical information systems in the study of landscape changes, the impact of farmers' livelihood strategies and the multiple factors conditioning changes in local resource management systems.

KEYWORDS: natural parks, population, counter-narrative, ethno-agronomy, remote sensing, Guinea-Bissau. 